\title{
RESEARCH
}

Open Access

\section{Verification of foetal Down syndrome biomarker proteins in maternal plasma and applications in prenatal screening for Down syndrome}

Weiguo Sui ${ }^{1+}$, Qing Gan ${ }^{1+}$, Wei Wei Gong ${ }^{1}$, Xiaolian Wei ${ }^{2}$, Minglin Ou ${ }^{1}$, Donge Tang ${ }^{3}$, Huanyun Jing ${ }^{1}$, Hua Lin ${ }^{1}$, Yue Zhang ${ }^{1}$ and Yong Dai ${ }^{1,3^{*}}$ (D)

\begin{abstract}
Background: Down Syndrome (DS) has a very high morbidity, according to statistics, the incidence rate of DS is as high as 1:700 among the new born babies. At present, there are still no effective prevention or treatment methods for the disease. We used a Western Blot technique to validate differentially expressed proteins between DS foetal umbilical cord blood plasma and healthy foetal peripheral blood plasma from pregnant women to identify new prenatal diagnostic biomarkers for down syndrome (DS) and establish a new non-invasive prenatal diagnosis method.
\end{abstract}

Methods: We collected maternal peripheral blood (8 with foetal DS and 8 from normal foetuses) from April 2013 to January 2014, and separated the plasma. We combined the clinical characteristics and clinical differentially expressed proteins between DS foetal umbilical cord blood plasma and healthy foetal umbilical cord blood plasma to identify specific protein marker candidates and prepared monoclonal antibodies, which were then used for Western Blot technique to analyse the candidate markers.

Results: In the DS foetal maternal plasma, serum amyloid P-component, Apolipoprotein E, Nucleosome assembly protein 1-like 1, Complement factor B,ERO1-like protein alpha, 2-oxoglutarate dehydrogenase-like, and Thymosin beta 10 were up-regulated proteins compared to the healthy control group, and the DS group showed higher expression, which agreed with the results from the DS foetal umbilical cord blood plasma.

Conclusion: The up-regulated amyloid P-component, Apolipoprotein E, Nucleosome assembly protein 1-like 1, Complement factor B, ERO1-like protein alpha, 2-oxoglutarate dehydrogenase-like, Thymosin beta 10 all are upregulation, all of them have potential to be prenatal diagnosis biomarkers for DS, and these biomarkers can further reveal the pathogenesis of DS.

Keywords: Biomarkers, Down's syndrome, Maternal blood plasma, Prenatal screening, Western blot

\footnotetext{
* Correspondence: daiyong22@aliyun.com

${ }^{+}$Weiguo Sui and Qing Gan contributed equally to this work.

${ }^{1}$ Nephrology Department of Guilin No. 181 Hospital, Guangxi Key laboratory

of Metabolic Diseases Research, Guilin Key laboratory of Kidney Diseases

Research, Guilin 541002, Guangxi, China

${ }^{3}$ Clinical Medical Research Center, the Second Clinical Medical College of

Jinan University (Shenzhen People's Hospital), Shenzhen, Guangdong 518020,

People's Republic of China

Full list of author information is available at the end of the article
}

(c) The Author(s). 2018 Open Access This article is distributed under the terms of the Creative Commons Attribution 4.0 International License (http://creativecommons.org/licenses/by/4.0/), which permits unrestricted use, distribution, and reproduction in any medium, provided you give appropriate credit to the original author(s) and the source, provide a link to the Creative Commons license, and indicate if changes were made. The Creative Commons Public Domain Dedication waiver (http://creativecommons.org/publicdomain/zero/1.0/) applies to the data made available in this article, unless otherwise stated. 


\section{Background}

Down's Syndrome (Down Syndrome, DS), trisomy of chromosome 21, mongolism or DS is the most common paediatric euchromosome aberration birth defect caused by diseases [1] and is associated with a number of deleterious phenotypes, including cognitive impairment, heart defects, childhood leukaemia and altered immune responses [2]. These deleterious phenotypes are thought to result from interactions between chromosome 21 (Hsa21) genes and Hsa21 genes interacting with other disomic genes [2, 3].

As one of the most common birth defect genetic diseases associated with chromosome aneuploidy, DS was first completely described in 1866 by Dr. John Langdon Down. It was confirmed that DS is caused by a chromosome abnormality in 1959 [4]. DS has a very high morbidity; according to statistics, the incidence of DS is as high as 1:700 among newborn babies [5]. At the present, there are no effective prevention and treatment methods for the disease. Traditional prenatal screening and prenatal diagnosis have some shortcomings, and new methods for non-invasive prenatal diagnosis are restricted by various factors in their clinical application. Amniotic cavity puncture, chorion, and umbilical cord blood sampling of prenatal diagnosis are traumatic and lead to complications such as bleeding, infection and spontaneous abortion [5, 6]. Additionally, traditional prenatal screening has a high error rate and produces false positives [7]. The combination of alpha fetoprotein (AFP), human choionic gonadotophin (HCG), free estriol (uE3) and inhibin A is the most popular method to screen for the disease. However, studies have shown that its detection rate is merely $60-75 \%$ with a $5 \%$ false positive rate [8].

It is important to find a safe and effective screening method. One such strategy is to look for new potential biomarkers using non-invasive proteomic approaches. Recent research on whole genome protein relative quantitation in maternal blood from pregnancies with DS foetuses has shown that some proteins show significantly different expression compared with normal maternal blood, which provided a theoretical basis to identify specific DS foetal protein markers from maternal blood [9]. The umbilical cord is a bridge between the mother and foetus where $\mathrm{CO}_{2}$ and $\mathrm{O}_{2}$, metabolic waste, and nutrient exchange occur. Hormones and proteins are also transferred from the mother to the foetus by the umbilical cord. Thus, we chose umbilical cord blood to investigate DS biomarkers because it may transfer proteins and growth factors into the maternal circulation system. The current study found that cell-free foetal DNA (cf-DNA) can be used to screen pregnant women with trisomy 21 with a lower false positive rate than maternal serum screening (MSS), which means better accuracy for detecting DS [10].
In our early work, we obtained proteome information from umbilical cord blood plasma from mothers with DS foetuses using Isobaric Tags for Absolute and Relative Quantitation (iTRAQ), which has been proposed for the discovery of plasma biomarkers [11].

In this work, we selected 7 proteins that are clinically significant and differentially expressed between umbilical cord blood plasma from pregnant women with DS foetuses and umbilical cord blood plasma from pregnant women with healthy foetuses as candidate biomarkers. We used Western Blotting to validate the candidates in maternal plasma to identify new biomarkers for a DS prenatal diagnostic and establish a new non-invasive prenatal diagnosis method.

\section{Methods}

Clinical samples and ethics statement

Sixteen maternal peripheral blood samples were collected from Shenzhen people's hospital in this study. All the women included in the study were between 26 and 46 years of age (mean of 30.0 years old) and were in the metaphase stage of pregnancy (the 16th to 18th week of gestation). Collected maternal blood from pregnant women who accepted an Oscar Test was immediately centrifuged at $12000 \mathrm{rpm} / \mathrm{min}$ for $15 \mathrm{~min}$. The plasma was separated into two $1.5 \mathrm{~mL}$ Eppendorf tubes and stored at $-80^{\circ} \mathrm{C}$ until further analysis.

Upon completion of the foetal karyotype, we had plasma from 8 women carrying a DS foetus and 8 women with normal foetuses. As mentioned in their medical files, all women used as controls gave birth at term and had no pregnancy-related complications.

This study was undertaken with the approval of Shenzhen people's hospital Human Subjects Review Committee, Guangdong, China. Written informed consent was obtained from all the pregnant women who participated in the study.

\section{Candidate markers}

We identified 7 proteins (Apolipoprotein E (ApoE), ERO1-like protein alpha (ERO1L), Serum amyloid P-component (SAP), Complement factor B, 2-oxoglutarate dehydrogenase-like (OGDHL), Nucleosome assembly protein 1-like 1 (NAP1L1), and Thymosin beta-10 (T $\beta 10)$ ) from proteome information and umbilical cord blood plasma with a DS foetus [11] as candidate biomarkers according to their clinical significance and differential expression in umbilical cord blood plasma.

\section{Antibodies}

All primary antibodies used in this study were provided by Abcam (Abcam Inc., Cambridge, MA, UK). The GAPDH (internal control) antibody was obtained from 
Kangcheng (Kangcheng Inc., Shanghai, China) and the secondary antibody, peroxidase-conjugated goat anti-rabbit IgG, was obtained from southern biotech (southern biotech Inc., Shanghai, China).

\section{Total protein extraction}

Double distilled water was added to plasma (1:1), shaken well and placed on ice. Then, $5 x$ loading buffer was added and the solution was mixed and boiled for $10 \mathrm{~min}$. After recovery at room temperature, the sample was centrifuged and stored at $-20^{\circ} \mathrm{C}$.

\section{Preliminary protein sample quantitation}

The standard sample was diluted according to Table 1 and the experimental sample was diluted 20 times. Then, $20 \mu \mathrm{l}$ from each experimental and standard sample was plated into a 96-well plate.

Next, $200 \mu \mathrm{l}$ of working liquid was added to each well and the plate was incubated for $30 \mathrm{~min}$ at $37^{\circ} \mathrm{C}$ in the dark. The following steps were performed according to kit's instructions (Nanjing KeyGEN Biotech. CO., LTD., Nanjing, China).

\section{SDS-PAGE, protein transfer and immunoblotting}

Briefly, $15 \mu \mathrm{g}$ of total protein lysate was loaded into precast $10-20 \%$ criterion SDS-PAGE gradient gels (Land, Guangzhou, China) and run under reducing conditions, followed by transfer to PVDF membranes (MILLIPORE).

The membranes were activated in methanol for $5 \mathrm{~s}$ and rinsed with TBST for $5 \mathrm{~min}$ (repeated three times) before blocking (5\% skimmed milk powder, $0.5 \%$ Tween 20 , and $1 \times$ TBS $[0.1 \mathrm{M}$ Tris- $\mathrm{HCl}$ and $0.5 \mathrm{M} \mathrm{NaCl0}$ ) overnight at $4{ }^{\circ} \mathrm{C}$. The membranes were incubated with primary antibodies at an appropriate diluted concentration for $2 \mathrm{~h}$ at $37^{\circ} \mathrm{C}$, followed by washing with TBST (repeated three times), incubation with the corresponding secondary goat anti-rabbit IgG antibody for $1 \mathrm{~h}$ at $37^{\circ} \mathrm{C}$ and further washing. Then, chemical glow fluorescent substrate was evenly placed on the surface of the membrane and it was incubated for $5 \mathrm{~min}$ and placed in the cassette for imaging (medical X-ray film was obtained from Kodak).

Table 1 the dilution of the standard sample

\begin{tabular}{llll}
\hline Vial & $\begin{array}{l}\text { Volume of } \\
\text { Diluent }\end{array}$ & $\begin{array}{l}\text { Volume and source } \\
\text { of BSA }\end{array}$ & $\begin{array}{l}\text { Final BSA } \\
\text { Concentration }(\mathrm{ug} / \mathrm{ml})\end{array}$ \\
\hline A & $70 \mathrm{ul} \mathrm{H2O}$ & 10ul BSA & 250 \\
B & $40 \mathrm{ul} \mathrm{H2O}$ & $40 \mathrm{ul} \mathrm{A}$ & $125 \mathrm{I}$ \\
C & $45 \mathrm{ul} \mathrm{H2O}$ & $30 \mathrm{ul} \mathrm{B}$ & 50 \\
D & $40 \mathrm{ul} \mathrm{H2O}$ & $40 \mathrm{ul} \mathrm{C}$ & 25 \\
E & $40 \mathrm{ul} \mathrm{H2O}$ & 10ul D & 5 \\
F & $40 \mathrm{ul} \mathrm{H2O}$ & & 0 \\
\hline
\end{tabular}

\section{Statistical methods}

The SPSS 17.0 statistical software was used for the analysis. Using the test, $P<0.05$ was considered statistically significant.

\section{Results}

\section{The standard curve}

The standard curve using BSA concentrations ( $\mathrm{x}$-axis) and the OD value (y-axis) is shown in Fig. 1. From the curve, we can see that the linear relationship is ideal, with $R^{2}=0.9945(R>0.98)$, suggesting that the protein concentration can be detected.

The OD value of each sample's total protein read from microplate reader is shown in Table 2. The total protein concentrations in the DS group were $27.677 \mu \mathrm{g} / \mu \mathrm{l}$, $25.610 \mu \mathrm{g} / \mu \mathrm{l}, \quad 27.456 \mu \mathrm{g} / \mu \mathrm{l}, \quad 29.503 \mu \mathrm{g} / \mu \mathrm{l}, \quad 30.015 \mu \mathrm{g} / \mu \mathrm{l}$, $29.804 \mu \mathrm{g} / \mu \mathrm{l}, 29.804 \mu \mathrm{g} / \mu \mathrm{l}$, and $30.236 \mu \mathrm{g} / \mu \mathrm{l}$. The total protein concentrations in the NC group were $29.222 \mu \mathrm{g} /$ $\mu \mathrm{l}, 29.042 \mu \mathrm{g} / \mu \mathrm{l}, 27.707 \mu \mathrm{g} / \mu \mathrm{l}, 28.871 \mu \mathrm{g} / \mu \mathrm{l}, 30.728 \mu \mathrm{g} / \mu \mathrm{l}$, $30.236 \mu \mathrm{g} / \mu \mathrm{l}, 29.042 \mu \mathrm{g} / \mu \mathrm{l}$, and $29.403 \mu \mathrm{g} / \mu \mathrm{l}$. We calculated the protein loading volumes for the DS group $(1.45 \mu \mathrm{l}, 1.56 \mu \mathrm{l}, 1.46 \mu \mathrm{l}, 1.36 \mu \mathrm{l}, 1.33 \mu \mathrm{l}, 1.34 \mu \mathrm{l}, 1.34 \mu \mathrm{l}$, and $1.32 \mu \mathrm{l}$, respectively) and the $\mathrm{NC}$ group $(1.37 \mu \mathrm{l}$, $1.38 \mu \mathrm{l}, 1.44 \mu \mathrm{l}, 1.39 \mu \mathrm{l}, 1.30 \mu \mathrm{l}, 1.32 \mu \mathrm{l}, 1.38 \mu \mathrm{l}$, and $1.36 \mu \mathrm{l}$, respectively).

\section{Western blot results}

The expressions of the candidate protein markers are shown in Fig. 2. There were obviously more bands in the DS group than the normal control group (Fig. 2a, b), and the DS group IOD value was higher (Fig. 2c). All the $P$ values were less than 0.05 (Table 3 ), as analysed by t test, so there were statistical significances between the DS and NC group candidates. OGDHL, SAP, ApoE, NAP1L1, T $\beta 10$, Complement factor $B$, and ERO1L were differentially expressed in the maternal blood plasma, with fold changes of 1.541, 1.336, 1.527, 2.188, 14.776, 2.567 , and 14.776 , respectively. $\mathrm{T} \beta 10$ showed the most obvious difference, with a fold change as high as 14.766, followed by ERO1L, with a fold change of 11.1.

\section{Discussion}

At present, many studies have studied the relationship between proteome and DS by various molecular techniques. Abdeldayem et al [12]. used Fisher score, Chi score, and correlation-based subset to select the most important proteins related to learning and memory from mouse model of DS. Wong [13] et al. found that amyloid precursor protein (APP) in DS placentas at RNA and protein levels had significant overexpression by qPCR, western blot, and immunohistochemistry. In this study, we reported on 7 proteins (OGDHL, SAP, ApoE, NAP1L1, T 310 , Complement factor $\mathrm{B}$, and ERO1L), that have been proven to be differentially expressed in umbilical cord blood from a pregnancy with a 


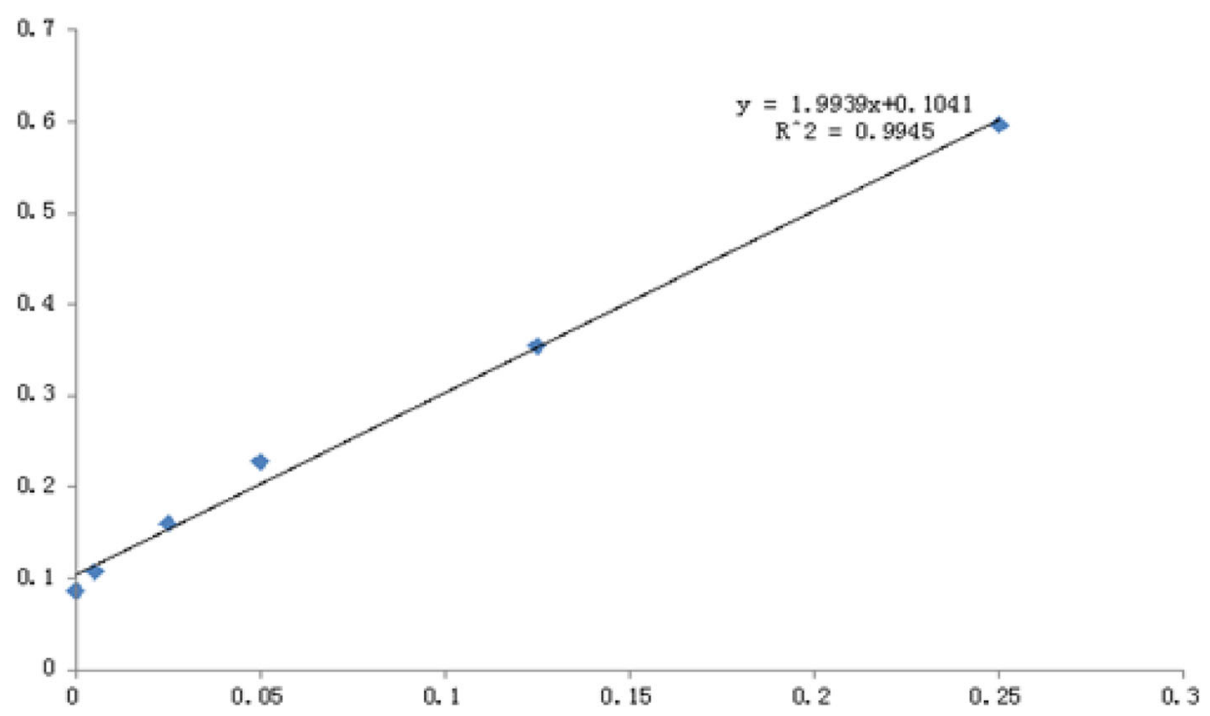

Fig. 1 Results of total protein concentration

DS foetus [10]. The expression of each candidate protein markers are shown in Fig. 2. It can be seen that the band of each candidate protein marker in the DS group is significantly more than that of the control group (Fig. 2a, b).The results showed that the seven candidate biomarkers were up-regulated in peripheral blood plasma from pregnant women with a DS foetus (Fig. 2c and Table 3), The candidate biomarkers were also up-regulated in umbilical cord blood from foetuses, showing basically identical results with the mother. Consequently, all 7 proteins are potential DS biomarkers.

ApoE, encoded by the Apolipoprotein E gene, contains 299 amino acids [14]. ApoE is present in most organs and participates in lipoprotein catabolism. Studies have reported that ApoE isomer specificity influences changes in nerve fibres and amyloid plaques [15, 16]. A series of articles focused on neuropathology have reported that apolipoprotein is associated with Alzheimer's disease (AD). $A D$ is a degenerative disease of the central nervous system characterized by progressive memory disorders, cognitive dysfunction, personality changes, and language barriers. Characteristic pathological changes also occur. For example, cells promote amyloid deposition $\beta$ that causes age spots and excessive phosphorylated tau protein that forms tangles in nerve cells, while neurons inhibit glial cell hyperplasia [17]. Pathology research has shown that E\&4 is also linked to Alzheimer's disease [18]. It is generally accepted that DS and early AD are related to the development of nervous pathological lesions [19]. Apolipoprotein E and nerve fibre changes in $\mathrm{AD}$ are associated with amyloid plaques, which are also present in patients with DS. Thus, we speculate that apolipoprotein $\mathrm{E}$ may be associated with the occurrence of DS. Serum amyloid P-component, which is composed of 233 amino acids, is a five polymer glycoprotein [20]. Serum amyloid P-component synthesis mainly occurs in the liver and can interfere with lipoprotein

Table 2 Each sample's total protein concentration and loading volume

\begin{tabular}{|c|c|c|c|c|c|c|c|}
\hline \multirow[t]{2}{*}{ Number } & \multicolumn{3}{|l|}{ DS } & \multicolumn{4}{|l|}{ NC } \\
\hline & OD value & $\begin{array}{l}\text { total protein } \\
\text { concentration ug/ul }\end{array}$ & loading volume ul & Number & OD value & $\begin{array}{l}\text { total protein } \\
\text { concentration ug/ul }\end{array}$ & loading volume ul \\
\hline 1 & 2.862 & 27.677 & 1.45 & 1 & 3.016 & 29.222 & 1.37 \\
\hline 2 & 2.656 & 25.61 & 1.56 & 2 & 2.998 & 29.042 & 1.38 \\
\hline 3 & 2.84 & 27.456 & 1.46 & 3 & 2.865 & 27.707 & 1.44 \\
\hline 4 & 3.044 & 29.503 & 1.36 & 4 & 2.981 & 28.871 & 1.39 \\
\hline 5 & 3.095 & 30.015 & 1.33 & 5 & 3.166 & 30.728 & 1.3 \\
\hline 6 & 3.074 & 29.804 & 1.34 & 6 & 3.117 & 30.236 & 1.32 \\
\hline 7 & 3.074 & 29.804 & 1.34 & 7 & 2.998 & 29.042 & 1.38 \\
\hline 8 & 3.117 & 30.236 & 1.32 & 8 & 3.034 & 29.403 & 1.36 \\
\hline
\end{tabular}




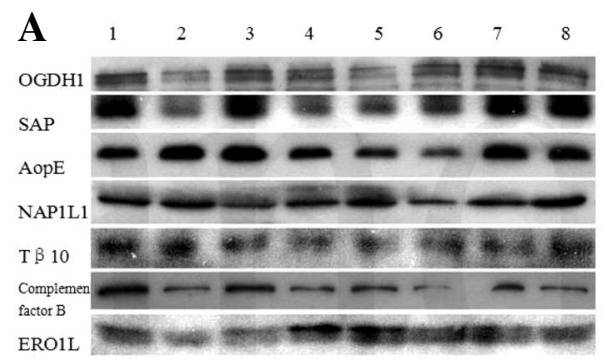

DS group

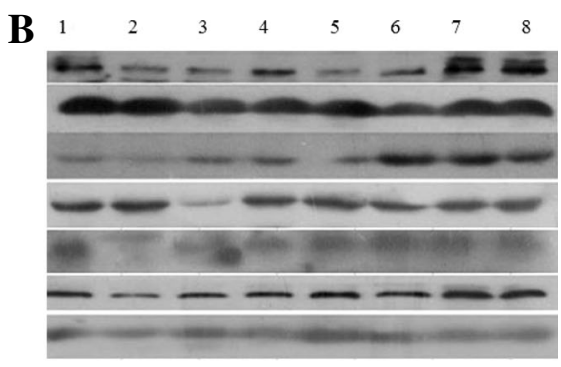

$\mathrm{NC}$ group

C

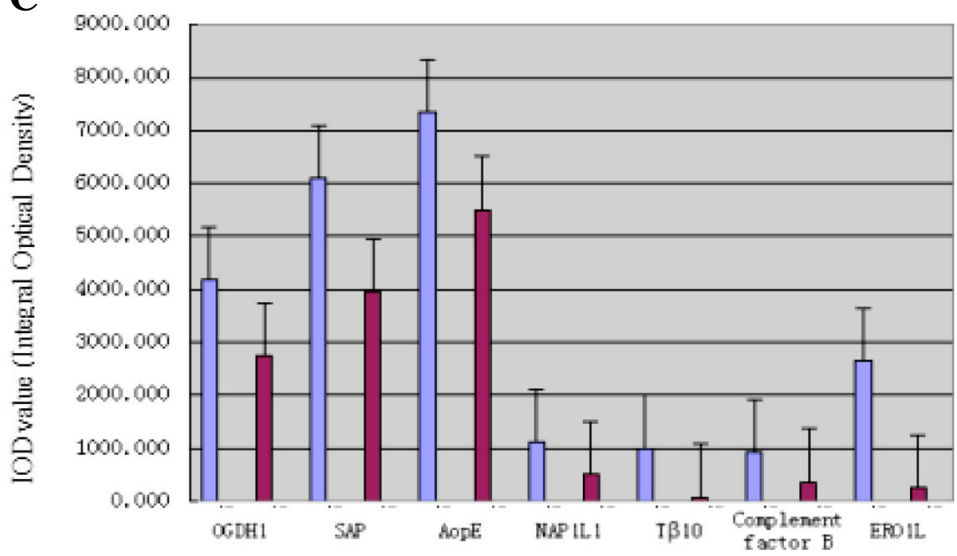

Fig. 2 The relative expression level of each candidate protein in DS group and NC group (a, western blot detects the expression level of each candidate protein marker in the DS group; (b), western blot detects the expression level of each candidate protein marker in the NC group; (c), differential expression analysis of candidate protein markers in DS group and NC group)

metabolism by activating and adjusting the complement system and participating in amyloid formation [21]. Serum amyloid P-component has been found in atherosclerotic plaques, the brains of patients with $\mathrm{AD}$ and type II diabetes amyloid plaque deposits [22]. Palumbo et al. also found that lipoprotein and serum amyloid P-component are present in amyloid deposits at the same time [23]. Research by Urbanyi et al. suggests that serum amyloid P-component plays an important role in neurodegenerative diseases such as $\mathrm{AD}$. The research also suggests that DS is associated

Table 3 Differentially expressed analysis of protein marker candidates

\begin{tabular}{lllllll}
\hline \multirow{2}{*}{$\begin{array}{l}\text { Name of } \\
\text { protein }\end{array}$} & \multicolumn{2}{l}{ IOD value } & Ratio & $\mathrm{t}$ & $v$ & $P$ value \\
\cline { 2 - 3 } \cline { 6 - 7 } & DS & NC & & & & \\
\hline OGDHL & 4175.15 & 2734.311 & 1.527 & 3.392 & 7 & 0.004 \\
SAP & 1060.39 & 272.948 & 1.541 & 5.241 & 7 & 0.001 \\
AopE & 931.223 & 1381.596 & 1.336 & 1.432 & 7 & 0.048 \\
NAP1L1 & 1104.078 & 504.591 & 2.188 & 3.164 & 7 & 0.016 \\
TB10 & 1000.59 & 67.761 & 14.766 & 6.381 & 7 & 0 \\
Complement & 919.313 & 358.087 & 2.567 & 4.104 & 7 & 0.005 \\
factor B & & & & & & \\
ERO1L & 2639.731 & 237.812 & 11.1 & 5.571 & 7 & 0.001 \\
\hline
\end{tabular}

with neurologically degenerative diseases [24]. This finding suggests that serum amyloid P-component may be associated with the pathogenesis of DS.

OGDHL is encoded by the OGDHL gene. The corresponding gene is localized in the q shoulders (cytogenetic band 10q11.23, OGDHL) of the 10th human chromosome [25]. OGDHL is a functionally active isoenzyme of oxoglutarate dehydrogenase (OGDH) and is present in brain tissue [26]. OGDHL and OGDH, which are components in the multienzyme OGDH complex (OGDHC), are preserved during purification and show comparable quantities to OGDH, which is the first and rate-limiting component in the multienzyme (OGDHC) whose malfunction is associated with neurodegeneration. Bunik [27] et al. analysed the non-parametric multipoint linkage of a high-resolution genome screen of 437 Alzheimer disease families and showed Alzheimer's disease linkage with the chromosome locus 10p14. In this study, OGDHL is upregulated, and its over expression may be associated with the pathogenesis of down's syndrome.

Thymosin $\beta 10$ (T $\beta 10)$ is a natural small molecule polypeptide that is widely distributed in many tissues with proven biological activities as an actin-sequestering 
protein involved in cell motility [28]. T $\beta 10$ is associated with cell proliferation, cell morphology, cell migration and endocytosis, as well as participating in cytoskeleton assembly and presence [29]. T $\beta 10$ is differentially expressed in embryogenesis and neurogenesis. Anadon [30] reported that 13-thymosin shows high expression levels in both process formation and in motor neurons, whereas its expression in adu neurons drops to undetectable levels in the developing rat cerebellum [31]. In recent years, Thymosin beta 10 has been reported to be associated with cancer biology [32]. In this study, we believe that $\mathrm{T} \beta 10$ overexpression may be associated with cognitive impairment in DS patients. Our results showed that the expression differences in $\mathrm{T} \beta 10$ could have significance for prenatal screening and the diagnosis of DS.

NAP1L1 belongs to the nucleosome assembly protein 1 (Nap1) family. Nap1L1 and Nap1 are highly homologous and are both histone molecular chaperones. It can also import histones into the nucleus, combine with DNA, and participate in gene transcriptional activation and mitosis [33]. Steer et al. reported that Xenopus NAP1L mRNA is predominantly expressed in oocytes than in adults, and it becomes progressively tissue-restricted as embryonic development progresses, suggesting that Nap1L1 is a maternal mRNA and has a prominent role in early development [34]. There are also some reports said that Nap1L1 plays an important role in the development of cardiac or stem cells that differentiate into myocardial cells. A study found that myocardial cell differentiation inhibits the expression of Nap1L1 in in vitro models and can promote iPS cell differentiation into myocardial cells, which may play a role by adjusting Notch signal channels [35]. Though NAP1L1 has been associated with embryonic development and the differentiation of myocardial cells, it has yet to be further studied to prove whether it is associated with DS.

Complement factor B, which is composed of 764 amino acids, is synthesized mainly by the liver and macrophages, plays an important role as a C3 convertase and is a complement system specificity factor that appears to bypass the activated pathway [36]. Strohmeyer et al [37]. reported that complement factor B is present in the frontal cortex in $\mathrm{AD}$ patients and its concentration is significantly increased, indicating the activation of the alternative pathway and suggests the favourable alternative pathway activation of chronic diseases found in Alzheimer's patient brains [38]. Research has also found that complement factor B was significantly increased in peripheral blood serum from pregnant women with DS foetuses. Additional studies suggested that complement factor B is associated with brain diseases and that there is a connection between DS and the complement system [39]; thus, it is speculated that complement factor B may be associated with brain damage in down's syndrome. In our study, the concentration of complement factor B in maternal blood plasma from a mother with a DS foetus was also significantly increased. Thus, we can assume that this protein can be used as a potential marker for DS prenatal diagnosis.

ERO1-L, is a flavoprotein that is mainly present in the endoplasmic reticulum; it is encoded by a gene located on chromosome 14 in humans [40]. ERO1-L-promoted endoplasmic reticulum stress can cause $\mathrm{Ca}^{2+}$ release, which triggers the apoptosis pathway. Studies have shown that ERO1-L and induced nitric oxide synthase (iNOS) participate in oxidative stress and inflammation induced by microglia [41, 42]. Neurons and oxidative stress induced by microglia are the main factor for the pathogenesis of neurodegenerative diseases such as Parkinson's disease and Alzheimer's disease [43]. AD often occurs in the DS patients at the age of thirty [44]; thus, ERO1-L $\alpha$ may be associated with pathogenesis of the DS, especially being related to cognitive impairment in patients with DS. In this study, ERO1-L in maternal plasma from mothers with a DS foetus was 2639.731, and 11.1 times higher than the control group. These significant differences in expression make it a potential biomarker for prenatal screening of DS.

\section{Conclusion}

We reported were up-regulated in DS foetal cord blood plasma and in maternal plasma from pregnant women with DS foetuses, demonstrating that the proteins have clinical significance. Thus, we believe the 7 proteins can be biomarker proteins for prenatal screening for down's syndrome. More testing and validation are needed for the application of these 7 proteins in the clinical as well as clarifying the pathogenesis of DS. These data will allow for the early diagnosis of DS. Absolutely, there are many popular molecular techniques that can be used to detect prenatal diagnostic markers such as Fisher score, Chi score, and correlation-based subset [12]. We will consider using these molecular techniques for further research.

The proteins serum OGDHL, SAP, ApoE, NAP1L1, $\mathrm{T} \beta 10$, Complement factor $\mathrm{B}$, and ERO1L are all up-regulated and have the potential to be prenatal diagnosis biomarkers for down's syndrome. Moreover, these biomarkers can further reveal the pathogenesis of DS.

\footnotetext{
Abbreviations

AD: Alzheimer's disease; AFP: Alpha fetoprotein; ApoE: Apolipoprotein E; APP: Amyloid precursor protein; cf-DNA: Cell-free foetal DNA; DS: Down Syndrome; ERO1L: ERO1-like protein alpha; HCG: Human choionic gonadotophin; Hsa21: Chromosome 21; iNOS: Induced nitric oxide synthase; iTRAQI: Isobaric tags for absolute and relative quantitation; MSS: Maternal serum screening; Nap1: Nucleosome assembly protein 1; NAP1L1: Nucleosome assembly protein 1-like 1; OGDH: Oxoglutarate dehydrogenase; OGDHC: OGDH complex; OGDHL: 2-oxoglutarate dehydrogenase-like; SAP: Serum amyloid P-component; T $\beta 10$ : Thymosin beta-10; T $\beta 10$ : Thymosin $\beta 10 ;$ uE3: Free estriol
} 


\section{Acknowledgments}

We thank the patients and healthy volunteers who participated in this study.

\section{Funding}

This work was supported by grants from the Scientific and Technological Research of Guilin Research and Technology Development Plan Project Contract (No. 20170109-34), Science and Technology Planning Project of Guangdong Province, China (No. 2017B020209001), Natural Science Foundation of Guangdong Province, China (No. 2017A030310629).

\section{Availability of data and materials}

Not applicable.

\section{Authors' contributions}

SWG and DY designed the study, analyzed the data and drafted the manuscript; WWG, XLW, MLO, DET, HYJ, HL and YZ acquired patient data and performed laboratory experiments; QG contributed to the study design and writing of the manuscript. All authors read and approved the final manuscript.

\section{Ethics approval and consent to participate}

This study was undertaken with the approval of the Institutional Ethical Board Shenzhen People's Hospital (Shenzhen, China). Written informed consent was obtained from all pregnant women and children participated.

\section{Consent for publication}

Not applicable.

\section{Competing interests}

The authors declare that they have no competing interests in this section.

\section{Publisher's Note}

Springer Nature remains neutral with regard to jurisdictional claims in published maps and institutional affiliations.

\section{Author details}

'Nephrology Department of Guilin No. 181 Hospital, Guangxi Key laboratory of Metabolic Diseases Research, Guilin Key laboratory of Kidney Diseases Research, Guilin 541002, Guangxi, China. ${ }^{2}$ College of Life Science, Guangxi Normal University, Guilin 541004, Guangxi, China. ${ }^{3}$ Clinical Medical Research Center, the Second Clinical Medical College of Jinan University (Shenzhen People's Hospital), Shenzhen, Guangdong 518020, People's Republic of China

\section{Received: 16 August 2018 Accepted: 8 November 2018}

Published online: 17 November 2018

\section{References}

1. Silverman D. The child as a social object: Down's syndrome children in a paediatric cardiology clinic. Sociol Health IIIness. 2010;3:254-74.

2. Xu Y, Li W, Liu X, Ma H, Tu Z, Dai Y. Analysis of microRNA expression profile by small RNA sequencing in Down syndrome fetuses. Int J Mol Med. 2013; 32:1115-25.

3. Elton TS, Sansom SE, Martin MM. Trisomy-21 gene dosage over-expression of miRNAs results in the haploinsufficiency of specific target proteins. RNA Biol. 2010;7:540-7.

4. Lejeune J, Gautier M, Turpin R. Etude des chromosomes somatiques de neuf enfants mongoliens. Compte Rendu d'Acad Sci. 1959;248:1721-22.

5. Avent ND. Maternal plasma biomarkers for Down syndrome: present and future. Drugs Today. 2013;49:145-52.

6. Yu B, Zhang B, Wang J, Wang QW, Huang RP, Yang YQ, et al. Preliminary proteomic-based identification of a novel protein for Down's syndrome in maternal serum. Exp Biol Med. 2012:237:530-9.

7. Gekas J, Durand A, Bujold E, Vallée M, Forest JC, Rousseau F, et al. Costeffectiveness and accuracy of prenatal Down syndrome screening strategies: should the combined test continue to be widely used? Am J Obstet Gynecol. 2011;204:171-8.

8. Kagan KO, Wright D, Baker A, Sahota D, Nicolaides KH. Screening for trisomy 21 by maternal age, fetal nuchal translucency thickness, free beta-human chorionic gonadotropin and pregnancy-associated plasma protein-a. Ultrasound Obstet Gynecol. 2008;31:618-24.
9. Ralhan R, Matta A, DeSouza LV, Shukla NK, Gupta SD, Ralhan R, Siu KW. Prognostic significance of head-and-neck cancer biomarkers previously discovered and identified using iTRAQ-labeling and multidimensional liquid chromatography-tandem mass spectrometry. J Proteome Res. 2008;7:2078-87.

10. Costa JM, Letourneau A, Favre R, Bidat L, Belaischallart J, Jouannic J, et al. Cellfree fetal DNA versus maternal serum screening for trisomy 21 in pregnant women with and without assisted reproduction technology: a prospective interventional study. Genetics in medicine official journal of the American College of Medical. Genetics. 2018. https://doi.org/10.1038/gim.2018.4.

11. Sui W, Zhang R, Chen J, He H, Cui Z, Ou M, et al. Quantitative proteomic analysis of Down syndrome in the umbilical cord blood using itraq. Mol Med Rep. 2015;11:1391-9.

12. Abdeldayem SS, Elhefnawi M. Deep feature selection for identification of essential proteins of learning and memory in mouse model of Down syndrome. PLOS. 2018. https://doi.org/10.1101/333849.

13. Wong OGW, Cheung CLY, Ip PPC, Ngan HYS, Cheung ANY. Amyloid precursor protein overexpression in Down syndrome trophoblast reduces cell invasiveness and interferes with Syncytialization. Am J Pathol. 2018;188: 2307-17.

14. Paik YK, Chang DJ, Reardon CA, Davies GE, Mahley RW, Taylor JM. Nucleotide sequence and structure of the human apolipoprotein $\mathrm{E}$ gene. Proc Nat Acad Sci. 1985:82:3445-9.

15. Schmechel DE, Saunders AM, Strittmatter WJ, Crain BJ, Hulette CM, Joo SH, et al. Increased amylold beta-peptide deposition in cerebral cortex as a consequence of apolipoprotein E genotype in late-onsset Alzheimer disease. Proc Natl Acad Sci U S A. 1993:90:9649-53.

16. Rebeck GW, Reiter JS, Strickland DK, Hyman BT. Apolipoprotein E in sporadic Alzhelmer's disease: allelic variation and receptor interactions. Neuron. 1993; 11:575-80.

17. McKhann G, Drachman D, Folstein M, Katzman R, Price D, Stadlan EM Clinical diagnosis of Alzheimer's disease report of the NINCDS-ADRDA work group* under the auspices of Department of Health and Human Services Task Force on Alzheimer's disease. Neurology. 1984;34:939-44.

18. Oyama F, Shimada H, Oyama R, Ihara Y. Apolipoprotein E genotype, Alzhelmer's pathologies and related gene expression in the aged population. Brain Res Mol Brain Res. 1995;29:92-8.

19. Hyman BT, West HL, Rebeck GW, Buldyrev SV, Mantegna RN, Ukleja M, et al. Quantitative analysis of senile plaques in Alzheimer disease: observation of log-normal size distribution and molecular epidemiology of differences associated with apolipoprotein E genotype and trisomy 21 (Down syndrome). Proc Natl Acad Sci U S A. 1995;92:3586-90.

20. Pasinetti GM. Inflammatory mechanisms in neurode generation and Alzheimer's disease: the role of the complement system. Neurobiol Aging. 1996;17:707-16

21. Steel DM, Whitehead AS. The major acute phase reactants. C-reactive protein, serum amyloid $\mathrm{P}$ component and serum amyloid a protein. Immunol Today. 1994;15:81-8.

22. Kiernan UA, Nedelkov D, Tubbs KA, Niederkofler EE, Nelson RW. Proteomic characterization of novel serum amyloid $P$ component variants from human plasma and urine. Proteomics. 2004;4:1825-9.

23. Griffin WS, Stanley LC, Ling C, White L, MacLeod V, Perrot LJ, et al. Brain interleukin I and S-100 immunoreactivity are elevated in Down syndrome and Alzheimer's disease. Proc Natl Acad Sci U S A. 1989:86:7611-5.

24. Borysov Sl, Granic A, Padmanabhan J, Walczak CE, Potter H. Alzheimer Abeta disrupts the mitotic spindle and directly inhibits mitotic microtubule motors. Cell Cycle. 2011;10:1397-410.

25. Koike K. Cloning, structure, chromosomal localization and promoter analysis of human 2-oxoglutarate dehydrogenase gene. Biochim Biophys Acta. 1998; 1385:373-84.

26. $\vee B$, Kaehne T, Degtyarev D, Shcherbakova T, Reiser G. Novel isoenzyme of 2-oxoglutarate dehydrogenase is identified in brain, but not in heart. FEBS J. 2008;275:4990-5006.

27. Blacker D, Bertram L, Saunders AJ, Moscarillo TJ, Albert MS, Wiener H, et al. Results of a highresolution genome screen of 437 Alzheimer's disease families. Hum Mol Genet. 2003;12:23-32.

28. Wang $H$, Jiang $S$, Zhang $Y$, Pan $K$, Xia J, Chen M. High expression of thymosin beta 10 predicts poor prognosis for hepatocellular carcinoma after hepatectomy. World J Surg Oncol. 2014;12:226.

29. Faa G, Gerosa C, Fanni D, Nemolato S, Di Felice E, Van Eyken P, et al. The role of immunohistochemistry in the study of the newborn kidney. J Matern Fetal Med. 2012;25:127-30 
30. Anadón R, Rodríguez Moldes I, Carpintero P, Evangelatos G, Livianou E, Leondiadis $L$, et al. Differentim: expression of thymosins $\beta 10$ and $\beta 10$ during rat eerebel-lure postnatal development. Brain Res. 2001;894:255-65.

31. Hall AK. Developmental regulation of thymosin 310 mRNA in the human brain. Brain Res Mol Brain Res. 1991;9:175-7.

32. Matthews PR, Eastwood SL, Harrison PJ. Reduced myelin basic protein and actin-related gene expression in visual cortex in schizophrenia. PLoS One. 2012;7:e38211.

33. Attia $\mathrm{M}$, Forster $\mathrm{A}$, Rachez $\mathrm{C}$, Freemont $\mathrm{P}$, Avner $\mathrm{P}$, Rogner UC. Interaction between nucleosome assembly protein 1-like family members. J Mol Biol. 2011;407:647-60.

34. Steer WM, Abu-Daya A, Brickwood SJ, Mumford KL, Jordanaires N, Mitchell J, et al. Enopus nucleosome assembly protein becomes tissue-restricted during development and can alter the expression of specific genes. Mech Dev. 2003;120:1045-57.

35. Guo X, Din X, Wang H, BAO P, Yan P. Gene expression of yak oocytes and preimplantation embryos derived from in vitro fertilization. Chin J Animal Veterinary Sci. 2013; 44:1576-81.

36. Zhou CC, Xue C, Wu M, Fu LL, Zhang YH, Wang WT, et al. JAK2-STAT3 pathway regulates the expression of complement factor $B$ in autosomal dominant polycystic kidney disease. China Med Abstracts. 2014;2:115.

37. Strohmeyer $R$, Shen $Y$, Rogers J. Detection of complement alternative pathway mRNA and proteins in the Alzheimer's disease brain. Brain Res Mol Brain Res. 2000;81:7-18.

38. Zhang B, Bin Y, Huang R, Shi Y, Cao F, Zhang $X$, et al. Preliminary research for the relevance on the concentration of complement factor B and Down's syndrome. China J Modern Med. 2012;22:35-38.

39. Masui S, Vavassori S, Fagioli C, Sitia R, Inaba K. Molecular bases of cyclic lation and more IC disulfide interchange between human ERO1 proteins and protein-disulfide isomerase (PDI). J Biol Chem. 2011;286:6261-71.

40. Zhao L, Cao CJ, Liu XM, Kong FQ, Ma WB, Zhou LX, et al. Role of ERO1a and its DNA methylation in homocysteine-induced inhibition of hepatocyte proliferation. Chin Pharma Bull. 2014;30:1743-7. https://doi.org/10.3969/j.issn. 1001-1978.2014.12.025

41. Araki K, Inaba K. Structure, Mechanism and evolution Ero1 family enzyme. Antioxid Redox Signal. 2012;8:790-9.

42. Ramming T, Appenzell Herzog C. Thephysiologlcal mammals function endoplasmic oxidoreductin 1: sulfide and more. Antioxid Redox Signal. 2012:10:1109-18

43. Casetta I, Govoni V, Granieri E. Oxidative stress, antioxidants and neurodegenerative diseases. Curr Pharm Des. 2005;11:2033-52.

44. Sun X, Wu Y, Chen B, Zhang Z, Zhou W, Tong Y, et al. Regulator of calcineurin 1 (RCAN1) facilitates neuronal apoptosis through caspase 3 activation. Biol Chem. 2011;286:9049-62.

Ready to submit your research? Choose BMC and benefit from:

- fast, convenient online submission

- thorough peer review by experienced researchers in your field

- rapid publication on acceptance

- support for research data, including large and complex data types

- gold Open Access which fosters wider collaboration and increased citations

- maximum visibility for your research: over $100 \mathrm{M}$ website views per year

At $\mathrm{BMC}$, research is always in progress.

Learn more biomedcentral.com/submissions 